\title{
Massive Ovarian Cyst - Is Surgery the Only Option?
}

\author{
Shailja Sharma ${ }^{1}$, Shashi Prateek², Latika Chawla ${ }^{3}$, Ankita Yadav ${ }^{4}$ Neetu Kochhar ${ }^{5}$ \\ 1, 2, 3, 4, 5 Department of Obstetrics and Gynaecology, AIIMS Rishikesh, Dehradun, Uttarakhand, India.
}

\section{INTRODUCTION}

Reproductive age group women face many challenges and disorders including ovarian masses. Ovarian cyst diagnosed in the reproductive age group are generally benign. ${ }^{1}$ Benign ovarian cysts, if diagnosed early when small $(<5 \mathrm{~cm}$ diameter $)$, usually resolve spontaneously and do not require surgical intervention whereas very large cysts (>10 cm in size) usually require surgical removal. ${ }^{2} \mathrm{~A}$ case of massive benign ovarian cyst in a reproductive age group woman, treated without a major surgical intervention is being reported.

Ovarian tumours like simple benign cysts (thin-walled cysts with no solid structures or calcifications) less than $5 \mathrm{~cm}$ diameter usually resolve over 2 menstrual cycles, out of which 10 percent of patients may undergo surgical intervention at some point during their lifetime, ${ }^{2}$ because of pain or perceived risk of torsion. But, on the other hand giant ovarian cysts undergo surgical removal by laparotomy or by endoscopy. Laparoscopy for removal of giant cysts $(>10 \mathrm{~cm})$ has gained importance. On its flipside, laparoscopic surgery has a few morbidities like formation of postoperative adhesions, which can compromise future fertility, although, less than laparotomy.

In the present case, a young unmarried childbearing age woman underwent ultrasound guided needle drainage of benign massive ovarian cyst for over 5 hours and 7.5 liters of fluid was removed with shorter duration of hospital stay and follow up was done in OPD. After 3 months of follow up, the patient has no symptoms, cyst size had not increased, and she was leading a normal life. In young women, it is also desirable to avoid unnecessary surgery as much as we can, to avoid complications and risks, keeping future fertility in mind. The management rationale is to do conservative management where possible and prevent or reduce patient morbidity by avoiding surgical methods like laparotomy and laparoscopic operations wherever possible after proper patient selection.

\section{PRESENTATION OF CASE}

An eighteen years old unmarried female came to gynaecology OPD of AIIMS Rishikesh with complaints of gradually progressive abdominal distension since one year, with regular menstrual cycles.

She was afebrile, pulse 102 / min, blood pressure 110 / $70 \mathrm{mmHg}$. There was no pallor, cyanosis, icterus, oedema, and lymphadenopathy. Secondary sexual characters were well developed. Systemic examination was normal. On per abdominal examination, there was about 28 week's size mass in abdomino-pelvic region. Patient was admitted. Routine blood and urine investigations were normal. Computed tomography (CT) Abdomen and pelvis revealed well defined, large thin walled cystic mass, in right ovary measuring $24 \times 12 \mathrm{~cm}$ with no solid contents / calcification, ultrasound guided needle tapping of massive ovarian cyst was done and 7.5 litre colourless clear fluid was drained over 5 hours and was sent for cytological examination which showed a cellular and proteinaceous material only with no atypical malignant cells. Gentamicin $80 \mathrm{mg}$, Metronidazole $500 \mathrm{mg}$, Ceftriaxone $1 \mathrm{gm}$ and Hydrocortisone succinate were injected in the cyst after the procedure before taking out the needle. After aspiration ultrasound was repeated which showed a cystic lesion of size of $300 \mathrm{cc}$ volume. Patient was discharged next day and further followed up in OPD. In follow up after 3 months the cyst volume has not increased and rather decreased to $100 \mathrm{~mL}$.
Corresponding Author: Dr. Ankita Yadav, Department of Obstetrics and Gynecology. AIIMS Rishikesh- 249203, Dehradun, Uttarakhand, India

E-mail: ankitayadav28101992@gmail.com

DOI: $10.14260 / \mathrm{jemds} / 2020 / 659$

How to Cite This Article:

Sharma S, Prateek S, Chawla L, et al. Massive ovarian cyst - is surgery only a option? J Evolution Med Dent Sci 2020;9(40):3014-3015, $10.14260 /$ jemds/2020/659

Submission 11-06-2020,

Peer Review 26-08-2020,

Acceptance 04-09-2020,

Published 05-10-2020.

Copyright (C) 2020 Shailja Sharma, et al. This is an open access article distributed under Creative Commons Attribution License [Attribution 4.0 International (CC BY 4.0)] 


\begin{tabular}{|c|c|c|c|}
\hline TLC & $7242 / \mu \mathrm{L}$ & Sodium & $149 \mathrm{mEq} / \mathrm{dL}$ \\
\hline Neutrophils & $62.74 \%$ & BUN & $14 \mathrm{mg} / \mathrm{dL}$ \\
\hline Lymphocytes & $26.55 \%$ & Creatinine & $0.67 \mathrm{mg} / \mathrm{dL}$ \\
\hline Monocytes & $8.39 \%$ & SGOT & $14.0 \mathrm{U} / \mathrm{L}$ \\
\hline Eosinophils & $1.68 \%$ & SGPT & $11.6 \mathrm{U} / \mathrm{L}$ \\
\hline Platelets & $170 \times 10^{3} / \mu \mathrm{L}$ & Total Protein & $6.4 \mathrm{~g} / \mathrm{dL}$ \\
\hline Hemoglobin & $12.95 \mathrm{~g} / \mathrm{dL}$ & Albumin & $4.20 \mathrm{~g} / \mathrm{dL}$ \\
\hline PT / INR & 1.17 & Serum LDH & $403.2 \mathrm{U} / \mathrm{L}$ \\
\hline Reticulocytes & $6.01 \%$ & TSH & $1.31 \mu \mathrm{IU} / \mathrm{mL}$ \\
\hline CRP & $38.938 \mathrm{mg} / \mathrm{dL}$ & CA $19-9$ & $25.9 \mathrm{U} / \mathrm{mL}$ \\
\hline Beta hCG & $<1.2 \mathrm{mIU} / \mathrm{mL}$ & AFP & $1.06 \mathrm{ng} / \mathrm{mL}$ \\
\hline Serum CEA & $1.2 \mathrm{ng} / \mathrm{mL}$ & & \\
\hline \multicolumn{4}{|c|}{ Table 1. Investigations } \\
\hline
\end{tabular}
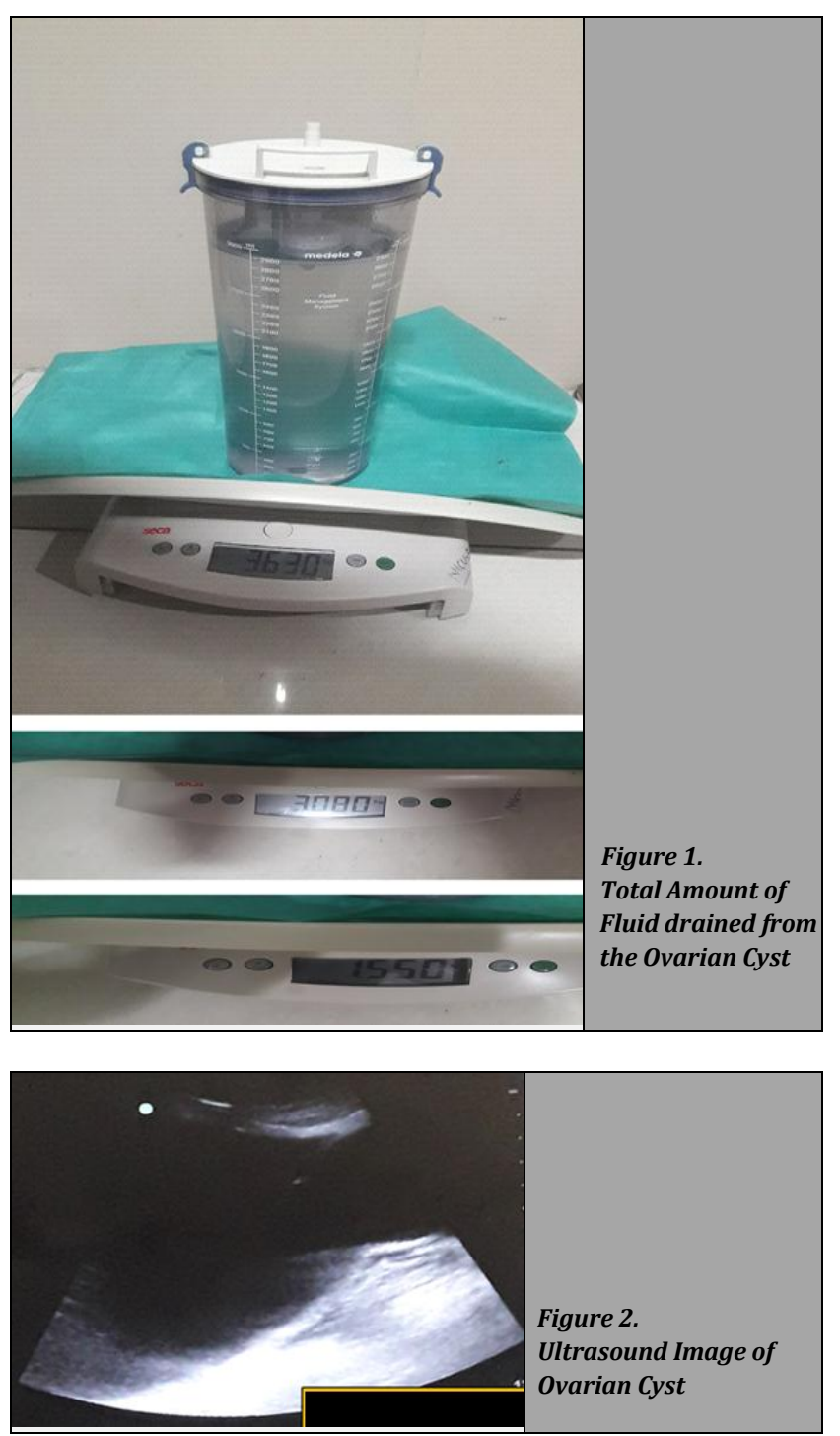

\section{DISCUSSION}

Ovarian cyst has been increasingly a common cause for hospital admission in the last decade constituting $90 \%$ of all ovarian tumours and has been affecting the women in the reproductive age group the most. ${ }^{3,4}$ Most of the times, it goes undetected being asymptomatic (symptomatic in 1:1000 in premenopausal women ${ }^{2}$ but in this new era, incidence of ovarian cysts is attaining peak due to better diagnosing facilities like ultrasound. ${ }^{1}$

Ovarian tumour like simple benign cysts (thin-walled cysts with no solid structures or calcifications) less than $5 \mathrm{~cm}$ diameter usually resolve over 2 menstrual cycles, ${ }^{2}$ out of which 10 percent of patients may undergo surgical intervention at some point during their life time, ${ }^{2}$ because of pain or perceived risk of torsion. ${ }^{1}$ But, on the other hand giant ovarian cysts undergo surgical removal by laparotomy or by endoscopy. Laparoscopy for removal of giant cysts $(>10 \mathrm{~cm})$ has gained immense importance. ${ }^{5-8}$ Salem reported around 15 cases of large benign ovarian cysts removed laparoscopically ${ }^{5}$. On its flipside, laparoscopic operation also has few morbidities like formation of post-operative adhesions, which can compromise future fertility, although, less than laparotomy. ${ }^{1,6}$

\section{CONCLUSIONS}

The management rationale is to do conservative management wherever possible and prevent or reduce patient morbidity by avoiding surgical methods like laparotomy and laparoscopic operations after proper patient selection.

Financial or Other Competing Interests: None.

\section{REFERENCES}

[1] Prakash A, Li TC, Ledger WL. The management of ovarian cysts in premenopausal women. Obstetrician \& Gynaecologist 2004;6(1):12-5.

[2] Management of suspected ovarian masses in premenopausal women. Green- top Guideline No. 62 RCOG/BSGE Joint Guideline 2011.

[3] Day NE, Krishnan E. Epidemiology of gynaecological cancers. In: Shaw RW, ed. Gynaecology. $2^{\text {nd }}$ edn. Edinburgh: Churchill Livingstone 1997;477-87.

[4] Yogambal M, Arunalatha P, Chandramouleeswari K, et al. Ovarian tumours- incidence and distribution in a tertiary referral center in south India. IOSR J Dent Med Sci 2014;13(2):74-80.

[5] Salem HA. Laparoscopic excision of large ovarian cysts. J Obstet Gynaecol Res 2002;28(6):290-4.

[6] Shindholimath VV, Jyoti SG, Patil KV, et al. Laparoscopic management of large ovarian cysts at a rural hospital. J Gynecol Endosc Surg 2009;1(2):94-7.

[7] Baradwan S, Sendy F, Sendy S. Complete laparoscopic extirpation of a giant ovarian cyst in an adolescent. Case Rep Obstet Gynecol 2017;2017:7632989.

[8] Diop B, Niang MM, Ba PA, et al. Management of giant ovarian cysts: a review of 5 case reports. J Gynecol Surg 2016;32(3). 